\title{
Review on the Research of the Ancient Village Protection and Development
}

\author{
Jinling Li \\ Yantai Nanshan University \\ Yantai, China
}

\author{
Shuangqing Hou \\ Yantai Nanshan University \\ Yantai, China
}

\begin{abstract}
The research on ancient village in China began in 1980s. When the protection of intangible cultural heritage grows vigorously, the confirmation of value and assessment of ancient villages, ecological research on folk culture, architectural feature, tourism planning and strategy have become key points of development and research of ancient village. This article summarizes and teases the research on ancient village protection and development, focuses on the analysis of research results and research methods, in order to acquire the direction and key points of specific research on ancient village protection and development.
\end{abstract}

\section{Keywords—ancient village; protection and development}

\section{CONCEPT DEFINITION ON ANCIENT VILLAGE}

There isn't a unified standard for the concept definition of ancient village. Liu Peilin thinks that ancient village is preserved from ancient times. The region of villages is largely unchanged. The environment, architecture, historical context and traditional atmosphere of villages are wellpreserved. Ancient villages can be seen in modern environment (except for human, the principle part of villages). ${ }^{1}$ Meanwhile, he refers to that the concept of ancient village is much the same as historic and cultural village or traditional villages. ${ }^{2}$ Ding Huaitang thinks that ancient villages must satisfy the following four conditions: firstly, ancient villages must have relatively long history and this history is remembered in this village; secondly, it has rich historic and cultural relics, which include the tangible and the intangible; thirdly, it basically reserves the system of the original village; fourthly, it must have distinctive local characteristics. $^{3}$ Mr. Feng Jicai thinks that ancient village should conform to the following standards: the tangible cultural heritage should create a system of its own and have a large number of historical and cultural relics, including village planning that integrates with nature, historical blocks, representative residential buildings, some public facilities,

\footnotetext{
${ }^{1}$ Liu Peilin, Ancient Village: Harmonious Living Space, Shanghai: Shanghai Erlian Bookstore, 1997: 6

${ }^{2}$ Liu Peilin, Ancient Village: Local Culture Issues in Urgent Need of Research, Journal of Hengyang Normal University, in 1997, the Second Edition in the 18th Volume.

${ }^{3}$ Ding Huaitang, Thinking on Strengthening the Protection of Ancient Village in Construction of New Countryside, Huizhou Social Science, the 6th edition in 2007, 17-18

Chinese library classification No.: TU984.2 Document code A
}

such as temple, bridge, well, drama stage, etc. At the same time, it has relatively distinct regional characteristics and intangible cultural heritage. ${ }^{4}$ Professor Zhu Xiaoming thinks, "The so-called ancient village refers to the villages constructed before the Republic of China. It reserves the major historical development; that is to say, the built environment, architectural scene and the choice of village location have no big changes and unique folk customs. Although having a very long period, it still has served people until now. As complete living unit and influenced by accidental factors of booms and busts in historical development, it keeps complete space structure and leaves many traditional construction sites and includes rich traditional lifestyle and has become new type of cultural relics." 5

\section{REVIEW ON OVERSEAS AND DOMESTIC RESEARCH STATUS AND RESEARCH SIGNIFICANCE}

\section{A. View of Research on Domestic Ancient Villages}

In 2012, our country launched the conservation reserve program of "Traditional Chinese Village", which is jointly implemented by Department of Housing Construction, Ministry of Culture, Cultural Relics Bureau and Ministry of Finance. They choose, name and protect typical and representative villages. On this basis, since the year of 2014, China Literary Federation, China Society of the Study of Folk Literature and Art, Chinese Photographers Society have implemented the project of "Establishing Files to Investigate Traditional Chinese Villages", used excellent picture and accompanying essay to register the name, forming reason, tangible cultural heritage and conservation status of each village. Mr. Feng Jicai, the master of culture, says, "We should use standard means to record our traditional villages, leave great creation of Chinese nation and great wealth of our agriculture civilization to later generations in the form of files, which is a historic work."

"The Eleventh Five-year Plan" in China places "construction of socialism new countryside" on the new level of "major historical tasks in the modernization process

\footnotetext{
${ }^{4}$ Feng Jicai, Villages Are Suffering from Destructive Development, publishing time: March 5, 2009, citing time: December 22, 2010

5 Zhu Xiaoming, Discussion on Evaluation Criterion of Ancient Village, Traditional Chinese Architecture and Gardens, the 4th edition in 2001
} 
in our country". Researches on problems appeared in construction and update of villages gradually increase. Besides, on the basis of previous researches, the research fields and perspectives expand significantly. From the perspective of research, it mainly includes:

1) Update and research on villages based on the perspective of living environment. Wu Liangyong: discuss different living environments under the theoretical guidance of sciences of human settlements, and research traditional village forms and its development.

Zhou Qinghua: Series of Sciences of Human Settlements, Loess Plateau, Human Settlements in River Valley: Research on Spatial Forms and Models of Living Environment in Northern Part of Shaanxi Province, take the spatial form of living environment of human settlement in river valley area of northern Shaanxi as research object, emphatically put forward three levels of feasible pattern of spatial form evolution of living environment.

Li Zhigang: Research on Living Environment Protection and Development Patterns in Hexi Corridor; take the area of Hexi Corridor that has weak ecological environment as research object, under the dual guidance of following natural ecological law and economic and social law.

Professor Zhai Hui: Shangri-La Utopian Ideal City: Research on Living Environment in Shangri-La Area, take the living environment in "Shangri-La area" as research object; put forward some suggestions and assumptions on the construction of "living environment in Shangri-La".

Chang Qing: Explore the Way of Regeneration of Natural Conditions and Social Customs of Human SettlementTaking the Experiment on Shanghai Jinze Ancient Town as an Example, take the historical and cultural town in suburb of Shanghai as research object, think that regional features such as settlement culture of combination of town and country are disappearing and put forward corresponding regeneration model about how to protect and regenerate this kind of traditional residential area.

Shen Yifan: Protection and Update of Street Space of Traditional Villages-Taking the "Display Area of Folk History and Culture" in Jinqiu Village as an Example, take traffic space of traditional villages as research object to adapt to the development of modern society through transforming it.

2) Research on village reconstruction based on the perspective of resources and industry. Many researched special topics, issues, thesis and reports and practice projects concentrate mainly on the development and utilization of regional ancient village tourism resources (the analysis of resource, value evaluation and model), historical and cultural value of ancient villages, architecture and culture of ancient villages (architectural feature, religion and culture), ancient village development mode (museum, business development, original development and community participation, etc.), site selection and layout of ancient villages, mainly research from the perspective of architecture and tourism development, and ignore doing researches on protection and inheritance of folk customs that intensively reflect the style and characteristics of ancient villages from aspects such as material folk culture, folk custom of social life and spiritual life.

\section{B. Mode of Overseas Study}

In Foreign Countries, people pay attention to comprehensive research on subjects: most researchers attach importance to absorbing results of other subjects, carefully do field investigation by going deep into traditional villages from the multidisciplinary perspectives such as anthropology, history, cultural ecology, geography, architecture and folklore, and analyze many phenomena caused by traditional village tourism. The research modes can be divided into the following kinds:

1) Conservation-Driven mode.Establish protection zone of resources and environment, and carry out ecological tourism construction of traditional villages with weak natural environment. For example, Grande Riviere is a traditional village in Trinidad in Caribbean area. The Grande Riviere Environmental Awareness Trust that focuses on protecting leatherback turtle was established in 1992. It transforms this traditional village industrial structure from cocoa producing area into protection zone of leatherback turtles. And this place finally becomes an important sightseeing district.

2) National Development Strategy driving mode. In order to balance regional development, our country always formulates strategy of regional integration development and drives the tourism of traditional villages through national development strategy. In England, in order to promote the tourism marketing of rural small communities within the scope of the state, tourism management departments have constructed "the concept of the country village weekend break" and popularized it in the eligible areas. The forms of tourism development of traditional villages brought by this had achieved success in 1990.

3) Rural Tourism driving mode. The forms of tourism guided by the market promote the development of traditional village tourism. Villages in Japan are historical and cultural treasure houses. People in Japan take villages as sources of life. In China, rural tourism is seen as "ritual of reversal" of city life. Most of Japan's traditional village tourisms under the background of rural tourism are driven by national identities.

\section{The Value and Significance of Researching Ancient Villages}

1) Expand all aspects of folklore studies. The reasons why traditional ancient villages can be inherited until now are that it has unique regional and architectural features, and its folk customs of material production, social life and spiritual life are basis to intensively reflect social and cultural style and features of ancient villages. Subdividing research contents helps to do systematic and classified research on specific appearance and things of folk custom. It also helps to better grasp all levels of ancient villages such as substance, culture, life, spirit, belief, religion and etiquette, and then find out the folklore inheritance and traditions. 
2) Historical and humanistic value. Traditional village is the largest place with maximal amount of information of cultural heritage in China. It has unique historical value and cultural value, and the value of witness of scientific "historic textual research" and research value, the academic value and educational value of "the annals of history" , and aesthetic value and appreciative value of "historical appearance" .

3) The value of intangible cultural heritage. Scholar Lou Yao said in his Discussion on Rules of Conduct of Custom that "the ethos of a country lies in custom and the basis of custom actually has relationships with rules of conduct." Ying Shao in the Eastern Han Dynasty said in his Preface of Fengsu Tongyi that "the key point of managing state is to identify and correct custom." Zheng Xiao said in the Discussion on Custom that "The so-called custom is implemented in imperial court and can be applied in the world. It runs through people's heart and relates to fate. People cannot do without it in everyday." The above cores of custom discussed by scholars in every dynasty lie in: the ethos of a country has close relationships with custom, while the essence and function of custom involve social order and law and discipline of a country. At the same time, in cultural dimension of modern society:

Firstly, inherit and protect historical and cultural heritage, embody the cultural self-consciousness of the state and the people;

Secondly, strengthen and protect traditional villages, continue the unique and distinct cultural tradition of all nations, protect the complete diversity of Chinese culture;

Thirdly, protect rural characteristics and improve the vitality of rural economy, promote the sustainable development of rural economy, society and culture.

\section{KEY POINTS AND INNOVATION OF RESEARCH ON ANCIENT VILLAGE PROTECTION AND DEVELOPMENT}

\section{A. Main Research Contents:}

1) Folk custom of material life in ancient villages.

- Folk custom of production (basic-level production of material goods such as agriculture, fisheries, mining, hunting and cultivation)

- Folk custom of industry and commerce (processing services of material goods such as handicraft industry, service industry and trade industry)

- Life folk custom (material consumption in food, clothing, shelter and transportation

2) Folk custom of social life in ancient villages.

- Folk custom of social organization (in aspects of family, village, community and mass organization)

- Folk custom of festivals at all seasons (time frame represented by solar terms and activities)
- Ceremonies of life (life course such as birth, birthday, adulthood, marriage and funeral)

3) Folk custom of spiritual life in ancient villages.

- Folk custom of entertainment (such as games, athletics and Shehuo)

- Concept of folk custom (spiritual world in the folk represented by worship of gods, legend, story and proverb)

\section{B. Basic Thought and Method of Research on Ancient Village}

1) Folk custom of material life. Material production is the basis of the survival of mankind. In the long-term production practice, people have concluded a series of effective production experience, production technology and even ceremonies of production related to it. Once this kind of folklore of production is formed, it will in turn affect all aspects of human society, such as their folk customs of clothing, diet, shelter and communication, and even aspects of people's spiritual world and social organization.

2) Folk custom of social life. Social custom: include family and ancestral culture, customary culture in life (folk culture of marriage and funeral), folk culture of festivals (structure and form of holidays). The issue pays attention to folk custom of festivals at all seasons and combines with social customs in Binhai.

3) Folk custom of spiritual life. It focuses on "custom belief" and etiquette of worshipful psychological idea that is popular in the masses.

\section{Research Emphasis:}

1) Folk custom of material life: The basis of agriculture and commerce, pay attention to folk custom of industry and commerce (processing services of material goods such as handicraft industry, traditional handicraft and trade industry)

2) Folk custom of social life: Folk custom of important festivals at all seasons in Binhai area (time frame represented by solar terms and activities)

3) Folk custom of spiritual life: Concept of folk custom (spiritual world in the folk represented by worship of gods, legend, story and proverb)

\section{Main Ideas:}

1) The maintenance of ecology of material folklore in ancient villages is the combination of architecture, folk custom, culture and spirit.

2) Changes of main material folklore in ancient villages in modern society

3) Contents of folk custom in the integral rural ancient villages in Binhai formed by folk custom of social life in ancient villages, appearance of folk custom and concept of folk custom 

life

4) Inheritance and difference of folk customs of spiritual

5) Influences and values of architectural landscape planning of ancient villages in the construction of modern new countryside

\section{E. Innovation}

1) Taking ancient village as the research object and using folk customs of material, social life and spiritual life to establish files and investigate can help to distinguish custom, folk fine arts, folk art and national and folk arts and crafts, and provide scope and limit for regional folklore studies.

2) Selecting key ancient villages on a national scale to research can accurately reflect historical inheritance of folk custom, architecture and landscape of ancient villages, and provide examples and cultural supports for rural construction in the new era and the reform of harmonious urbanization.

3) The national social planning clearly shows the cultural, historical and heritage value of ancient villages, which can promote and improve the self awareness of national and folk culture.

\section{ThreE LEVEls of ANCIENT VILlAGE PROTECTION AND DEVELOPMENT}

\section{A. Rescuing conservation - the basis of ancient village protection}

Because ancient village is nonrenewable and easily damaged, it requires us to put the rescuing conservation in the first place;

Use words, pictures, recording, video and digital multimedia technology to truly and completely record inheritors (community and group) of intangible cultural heritage and pattern of manifestation of intangible cultural heritage grasped by them, and collect relevant physical objects and materials to establish complete file and database and store them in the system for convenient use.

\section{B. Dynamic and Integral Protection}

Establish cultural ecological protection zone and implement regional and integral protection. Regional and integral protection mainly refers to protect the intangible cultural heritage of ancient village as well as the natural environment and cultural environment related to it. It is a cultural ecological protection, emphasizes the original living state of culture and cultural continuation that does not separate from the native land and people, the sustainable and inheritable atmosphere of cultural tradition, and the maintenance of original style. Besides, it protects the cultural environment according to the development of its objective law and pays attention to the construction, maintenance and restoration of cultural ecological environment. The cultural ecological protection zone refers to focusing on protecting intangible cultural heritage and carrying out integral protection for cultural forms that have rich historical accumulation and good existing state, important value and distinct characteristics.

\section{Productive Protection}

Our country puts forward the concept of productive protection according to the fact that traditional skill of intangible cultural heritage, traditional art and projects of traditional medicine basically belong to traditional handicraft, and its cultural connotation and value of art should rely on manual creation of people and the process of production practice.

Productive protection refers to the protected mode in the practice process that has productive character, focus on maintaining the authenticity, integrality and inheritance of intangible cultural heritage as the core and use the ways of production, circulation and sales to change intangible cultural heritage and its resources as cultural products.

\section{REVIEW AND EXPECTATION}

The protection and development research of future ancient villages need to solve three problems:

1) The research on connected effect of cultural ecology and cultural economy of ancient villages. At present, many researchers focus the research on tourism development of ancient villages. Some researchers also think tourism is the strategic industry of ancient village development. However, tourism is not always the best choice of ancient village development, let alone the only choice. The recombination and integration of traditional national industry of ancient villages are also important aspects of ancient village protection and development.

2) Industrialization of ancient village development. Excavate advantages of ancient villages, make efforts to bring itself into the system of national ancient village protection, such as declare national historical and cultural village, apply for national protection money, and under the leadership of government, raise protection capital in multiple modes and channels to realize state that continuous reproduction breed in an endless succession of their culture.

3) Coordinate contradictions between construction of new countryside and ancient village protection and development. Integrate the configuration of resources superiority; for the ancient village and construction of new countryside, implement separate management, stage-wise management, level-to-level administration, and realize unification of administrative effect and social effect.

\section{REFERENCES}

[1] Feng Jicai, The Soul Cannot Kneel: Academic Analects of Feng Jicai's Cultural Heritage Thought, Yichuan: Ningxia Press 2007

[2] Wu Bingan: Principle of Folklore, Liaoning University Press, 2001

[3] Zhou Xing, editor-in-chief: History, Theory and Method of Folklore, the commercial press, 2006

[4] (Japan) Akira Fujii, Visit on Human Settlement [M], translated by Ning Jing, proofread by Wang Yun, Beijing: China Building Industry Press, 2003 
[5] (Japan) Hiroshi Hara, Instruction on Human Settlement in the World 100 [M], Beijing, China Building Industry Press, 2003 